\title{
HUBUNGAN KEWENANGAN PEMERINTAH PUSAT DAN DAERAH DALAM MENGURUS BIDANG PERTANAHAN DIHUBUNGKAN DENGAN HUKUM POSITIF
}

\author{
Tri Setiady \\ Fakultas Hukum Universitas Wiralodra Indramayu
}

\begin{abstract}
Law Number 32 of 2004 of governmental authority in the land sector remains handed over to the autonomous region. Law Number 32 of 2004 requires the district/city governments to conduct business in the area of land as part of the implementation of regional autonomy and a mandatory affair because it is so fundamental with regard to rights and basic services citizens. The affairs of the land sector is very essential as it relates to the issue of community rights to land. Therefore, the government must provide the public with regard to the maintenance in the land sector. But on the other hand the government has not completed the handover of authority in the field of regulation of land through implementing regulations.
\end{abstract}

Keywords: Central and Local Government Authority, Land and Legal Affairs Positive

\begin{abstract}
abstrak
Dalam UU No. 32 Tahun 2004 kewenangan pemerintahan di bidang pertanahan tetap diserahkan kepada daerah otonom. UU No. 32 Tahun 2004 mewajibkan Pemerintah Kabupaten/ Kota untuk menyelenggarakan urusan di bidang pertanahan sebagai bagian dari pelaksanaan otonomi daerah dan merupakan urusan yang bersifat wajib karena sangat mendasar yang berkaitan dengan hak dan pelayanan dasar warga negara. Urusan bidang pertanahan bersifat sangat mendasar karena berkaitan dengan persoalan hakhak masyarakat atas tanah. Oleh karena itu, pemerintah wajib memberikan pelayanan kepada masyarakat berkaitan dengan pengurusan di bidang pertanahan. Namun di sisi lain pemerintah belum menuntaskan regulasi penyerahan kewenangan di bidang pertanahan melalui peraturan pelaksana.
\end{abstract}

\section{Kata Kunci: Kewenangan Pemerintah Pusat dan Daerah, Bidang Pertanahan dan Hukum Positif}




\section{A. Pendahuluan}

Istilah wewenang seringkali disamaartikan dengan istilah kemampuan atau bevoegheid dalam ranah hukum perdata. Istilah wewenang sebenarnya tidak dapat disamakan dengan bevoegheid, karena kedua istilah tersebut mempunyai perbedaan yang mendasar berkaitan dengan karakter hukumnya. Bevoegheid digunakan dalam konsep hukum publik dan hukum privat, sedang istilah wewenang hanya berlaku dalam konsep hukum publik. Wewenang mengandung arti kemampuan untuk melakukan suatu tindakan hukum publik. Atau dengan perkataan lain, wewenang adalah kemampuan bertindak yang diberikan oleh undang-undang yang berlaku untuk melakukan hubungan dan perbuatan hukum. ${ }^{1}$

Kadangkala istilah wewenang dikaitkan dengan suatu kekuasaan hukum (rechtskracht). Terkait dengan kekuasaan hukum tersebut maka ada dua hal yang perlu diperhatikan, yakni berkaitan dengan keabsahan suatu tindak pemerintahan dan kekuasaan hukum. Istilah "sah" adalah pendapat atau pernyataan tentang suatu tindak pemerintahan, sedang "kekuasaan hukum" adalah mengenai kinerja. Suatu tindak pemerintahan dianggap "sah" jika dapat diterima sebagai suatu bagian dan ketertiban hukum, dan suatu tindak pemerintahan adalah mempunyai kekuasaan hukum jika dapat mempengaruhi pergaulan hukum. ${ }^{2}$

Wewenang merupakan bagian yang sangat penting dalam hukum tata pemerintahan (hukum administrasi), karena pemerintahan baru dapat menjalankan fungsinya atas dasar wewenang yang diperoleh. Keabsahan tindakan pemerintahan diukur berdasarkan wewenang yang diatur dalam peraturan perundang-undangan (legaiteit beginselen). Suatu kewenangan harus didasarkan pada ketentuan hukum yang berlaku sehingga bersifat sah. Perihal kewenangan dapat dilihat pada konstitusi negara yang memberikan legitimasi kepada badan publik dan lembaga negara dalam menjalankan fungsinya.

Suatu kewenangan dapat diperoleh dari tiga sumber, yaitu atribusi, delegasi, dan mandat. Kewenangan atribusi lazim digariskan melalui pembagian kekuasaan negara yang diatur dalam Undang Undang Dasar, sedang delegasi dan mandat merupakan suatu kewenangan yang berasal dari pelimpahan. Perbedaan antara kewenangan berdasarkan delegasi dan mandat menurut Philipus M. Hadjon adalah terletak pada prosedur pelimpahannya,

\footnotetext{
1 S.F. Marbun, Peradilan Administrasi Negara dan Upaya Administratif di Indonesia, (Yogyakarta: Liberty, 1997), hlm. 154.

${ }^{2}$ F.A.M Stroink, dalam Philips M.Hadjon, tentang Wewenang, sebagaimana dikutip Sadjijno, Memahami Beberapa Bab Hukum Administrasi, (Yogyakarta: LaksBang PRESindo, 2008), hlm. 59.
} 
tanggung jawab dan tanggung gugatnya, serta kemungkinan dipergunakannya kembali kewenangan tersebut. ${ }^{3}$

Dilihat dari prosedur pelimpahannya pada delegasi, pelimpahan wewenang terjadi dari suatu organ pemerintahan kepada organ pemerintahan lainnya, yang dilakukan berdasarkan peraturan perundang-undangan. Sedang pada mandat pelimpahan wewenang umumnya terjadi dalam hubungan rutin antara bawahan dengan atasan, kecuali yang secara tegas dilarang. Ditinjau dari segi tanggung jawab dan tanggung gugatnya, pada delegasi, tanggung jawab dan tanggung gugatnya beralih kepada delegataris, sedang pada mandat tetap berada pada pemberi mandat (mandans). Ditinjau dari segi kemungkinan pemberi wewenang berkehendak menggunakan kembali wewenang tersebut, pada delegasi pemberi wewenang (delegans) tidak dapat menggunakan wewenang itu lagi, kecuali setelah ada pencabutan dengan berpegang teguh pada asas contrarius actus, sedang pada pemberi mandat wewenang mandat (mandans) setiap saat dapat menggunakan sendiri wewenang yang dilimpahkan. ${ }^{4}$

Pengaturan kewenangan pemerintahan di bidang pertanahan diatur dalam undang-undang dasar dan undang-undang. Dalam Pasal 33 (3) UUD 1945 disebutkan bahwa bumi, air, dan kekayaan alam yang terkandung di dalamnya dikuasai oleh Negara dan dipergunakan sebesar-besarnya untuk kemakmuran rakyat. Dari kata "dikuasai oleh Negara" terlihat bahwa kewenangan di bidang pertanahan dilaksanakan oleh Negara yang dalam pelaksanaannya dilakukan oleh Pemerintah Pusat. Berdasarkan kewenangan yang bersumber pada konstitusi tersebut maka kemudian diterbitkan UU No. 5 Tahun 1960 yang mengatur masalah keagrarian atau pertanahan sebagai bagian dari bumi.

Di samping itu kewenangan di bidang pertanahan juga diatur dalam UU Pemerintahan Daerah, yaitu semula dalam UU No. 22 Tahun 1999 yang kemudian diganti dengan UU No. 34 Tahun 2004. Dalam Pasal 13 dan Pasal 14 UU No. 32 Tahun 2004 disebutkan bahwa urusan wajib yang menjadi kewenangan pemerintahan daerah (Provinsi dan Kabupaten/Kota) yang meliputi 16 bidang urusan, salah satunya adalah "pelayanan pertanahan". Keenam belas urusan (bidang) tersebut merupakan urusan pemerintahan yang bersifat wajib yang harus diselenggarakan oleh Pemerintah Daerah. Sedang urusan pemerintahan daerah yang bersifat pilihan meliputi urusan pemerintahan yang secara nyata ada dan berpotensi untuk meningkatkan

\footnotetext{
${ }^{3}$ Philipus M. Hadjon, 1994, Fungsi Normatif Hukum Administrasi dalam Mewujudkan Pemerintah yang Bersih, Pidato Pengukuhan Guru Besar UNAIR, Surabaya, 10 Oktober 1994, hlm. 8.

4 Suriansyah Murhaini, Kewenangan Pemrintah Daerag Mengurus Bidang Pertanahan, (Surabaya: LaksBang Justitia, 2009), hlm 15.
} 
kesejahteraan masyarakat sesuai dengan kondisi, kekhasan, dan potensi unggulan daerah yang bersangkutan.

Penyerahan kewenangan pemerintahan di bidang pertanahan berdasarkan UU No. 22 Tahun 1999 juga telah diserahkan kepada Daerah, namun dalam praktek tidak dapat berjalan seperti yang diharapkan oleh Pemerintah Kabupaten/Kota. Dalam Pasal 11 (2) UU No. 22 Tahun 1999 ditegaskan bahwa salah satu bidang pemerintahan yang wajib dilaksanakan oleh daerah (Kabupaten/Kota) adalah pertanahan. Berdasarkan kewenangan menurut Pasal 11 (2) UU No. 22 Tahun 1999 tersebut maka banyak pemerintah daerah (kabupaten/ kota) menganggap bidang pertanahan merupakan kewenangan daerah sehingga dibentuk Dinas Pertanahan untuk diurusi sendiri oleh Daerah. Di sisi lain, Pemerintah Pusat ternyata menunda penyerahan kewenangan di bidang pertanahan kepada Daerah (Kabupaten/ Kota).

Pemerintah menerbitkan PP No. 25 Tahun 2000 yang mengatur kewenangan di bidang pertanahan berkaitan dengan otonomi daerah. Dalam PP No. 25 Tahun 2000 dikatakan bahwa sebelum ditetapkan peraturan baru berdasarkan PP tersebut maka tetap berlaku peraturan, undang-undang, keputusan, instruksi, dan surat edaran Menteri Negara Agraria yang telah ada. Selanjutnya dalam Kepres No. 10 Tahun 2001 juga dinyatakan bahwa kewenangan di bidang pertanahan sesuai Pasal 11 (2) UU No. 22 Tahun 1999 akan diatur kemudian dalam Peraturan Pemerintah. ${ }^{5}$

Kemudian dalam Pasal 1 (6) Kepres 62 Tahun 2001 ditegaskan bahwa sebagian tugas pemerintahan yang dilaksanakan BPN di daerah tetap dilaksanakan oleh Pemerintah Pusat sampai ditetapkannya seluruh peraturan perundang-undangan di bidang pertanahan selambat-lambatnya dua tahun. Namun dalam Kepres No. 34 Tahun 2003 dikatakan bahwa pelaksanaan kewenangan Pemerintah Kabupaten/Kota di bidang pertanahan ditangguhkan. Dalam Pasal 3 ayat (2) Keppres No. 34 Tahun 2003 disebutkan bahwa penerbitan regulasi di bidang pertanahan bagi daerah akan dilaksanakan oleh BPN paling lambat tanggal 1 Agustus 2004. Hanya saja sampai lahirnya UU No. 32 Tahun 2004 belum ditemukan satupun peraturan yang diterbitkan oleh BPN mengenai penyerahan wewenang pengurusan pertanahan kepada Daerah Otonom. ${ }^{6}$

Ketentuan dalam Kepres No. 10 Tahun 2001, Kepres No. 62 Tahun 2001, dan Kepres No. 34 Tahun 2003 merupakan policy of nonenforcement (kebijakan untuk tidak menerapkan hukum) otonomi daerah di bidang pertanahan. Ketentuan tersebut harus ditaati oleh semua Pemerintah

\footnotetext{
${ }^{5}$ Ibid, hlm 17.

${ }^{6}$ Ibid.
} 
Kabupaten/Kota di seluruh wilayah RI, karena yang membuat peraturan itu adalah kepala pemerintahan negara tertinggi berdasarkan konstitusi.

Dalam UU No. 32 Tahun 2004 kewenangan pemerintahan di bidang pertanahan tetap diserahkan kepada daerah otonom. UU No. 32 Tahun 2004 mewajibkan Pemerintah Kabupaten/Kota untuk menyelenggarakan urusan di bidang pertanahan sebagai bagian dari pelaksanaan otonomi daerah dan merupakan urusan yang bersifat wajib karena sangat mendasar yang berkaitan dengan hak dan pelayanan dasar warga negara. Jadi, urusan bidang pertanahan bersifat sangat mendasar karena berkaitan dengan persoalan hakhak masyarakat atas tanah. Oleh karena itu, pemerintah wajib memberikan pelayanan kepada masyarakat berkaitan dengan pengurusan di bidang pertanahan. Namun di sisi lain Pemerintah belum menuntaskan regulasi penyerahan kewenangan di bidang pertanahan melalui peraturan pelaksana. Maka dalam artikel ini dirumuskan masalah yang hendak dikaji adalah: pertama, bagaimanakah kewenangan pemerintah pusat dan daerah dalam mengurus bidang pertanahan ditinjau dari peraturan perundang-undangan yang berlaku? Kedua, bagaimanakah hubungan kewenangan pemerintah pusat dan daerah dalam mengurus bidang pertanahan?

\section{B. Pembahasan}

1. Kewenangan Pemerintah Pusat dan Daerah dalam Mengurus Bidang Pertanahan Ditinjau dari Peraturan Perundang-Undangan yang Berlaku

\section{a. Kewenangan Pemerintah Pusat dan Daerah dalam Mengurus Bidang Pertanahan Menurut UUPA}

Kewenangan mengurus bidang pertanahan menurut UUPA ada pada negara yang dalam pelaksanaannya dilakukan oleh pemerintah pusat. Ketentuan dalam UUPA tersebut bersumber pada Pasal 33 UUD 1945 yang telah menentukan bahwa semua tanah adalah merupakan hak ulayat bangsa Indonesia sebagai karunia Tuhan Yang Maha Esa, yang penguasaannya ditugaskan kepada negara, dalam hal ini adalah pemerintah pusat. Kesemuanya itu dimaksudkan untuk menuju pada pencapaian sebesarbesarnya kemakmuran rakyat. Berdasarkan hak menguasai negara sebagaimana disebutkan Pasal 2 UUPA maka pemerintah pusat berwenang mengatur dan menetapkan berbagai segi peruntukan dan penguasaan tanah.

Penetapan dan pengaturan tersebut meliputi perencanaan peruntukan tanah, penguasaan, dan perbuatan hukum mengenai tanah serta pendaftaran tanah, yang pada kenyataannya selalu dilaksanakan oleh pemerintah pusat. Memang dimungkinkan dilakukan pelimpahan wewenang kepada pemerintah daerah atau daerah swantantra, namun pelimpahan tersebut dilakukan dalam rangka dekonsentrasi kepada pejabat-pejabat pemerintah pusat yang ada di daerah. Bisa juga pelimpahan wewenang tersebut 
diberikan kepada pemerintah daerah sebagai daerah otonom, tetapi hanya dalam rangka tugas pembantuan (medebewind), bukan desentralisasi atau otonomi daerah.

Memang dalamrangka otonomi daerah sebagaimana ditentukan UU No. 22 Tahun 1999 yang kemudian diganti dengan UU No. 32 Tahun 2004, urusan pertanahan dapat didesentralisasikan kepada pemerintah daerah. Dalam UU Pemerintahan Daerah ditentukan bahwa bidang pertanahan merupakan salah satu urusan wajib yang harus dilaksanakan oleh pemerintah daerah (Provinsi dan Kabupaten/Kota). Namun ketentuan tersebut tidak harus dicerna secara mentah atau dimaknai bahwa wewenang tersebut secara utuh berada pada Pemerintah Daerah. Menurut Arie Sukanti Hutagalung, wewenang yang dipunyai oleh pemerintah daerah di bidang pertanahan hanya sebatas yang bersifat lokalitas dan tidak bersifat nasional.?

Pemberian otonomi kepada daerah sebagaimana diatur dalam UU Pemerintah Daerah adalah berada dalam bingkai Negara Kesatuan RI, sehingga kebebasan untuk mengatur dan mengurus bidang pertanahan tetap dilakukan dalam rangka kebijakan dasar dan pokok-pokok ketentuan hukum pertanahan yang berlaku secara nasional. Hal ini dapat ditafsirkan dari katakata "sesuai peraturan perundang-undangan" sebagaimana yang disebutkan dalam undang-undang yang mengatur pemerintah daerah. Oleh karena itu, maka otonomi di bidang pertanahan yang dipunyai pemerintah daerah tidak harus diartikan bahwa pengaturan dan pengurusan segala segi masalah pertanahan beralih sepenuhnya menjadi wewenang pemerintah daerah, tetapi masih ada kewenangan pengaturan mengenai hal-hal yang bersifat pokok dan umum, serta pembinaan yang sepenuhnya dipunyai oleh Pemerintah Pusat.

Sehubungan dengan hal tersebut maka pemerintah perlu mengatur secara jelas kewenangan apa yang dipunyai oleh pemerintah pusat dan kewenangan mana yang didelegasikan kepada pemerintah daerah. Dari berbagai peraturan perundang-undangan yang mengatur masalah pertanahan sudah jelas ditentukan bahwa kewenangan pemerintah pusat di bidang pertanahan meliputi pembuatan produk hukum, kebijakan, pedoman mengenai pemberian hak-hak atas tanah, pendaftaran tanah, reformasi pertanahan (landreform), yang kesemuanya dituangkan dalam bentuk undang-undang, peraturan pemerintah atau peraturan presiden dan peraturan pelaksana lainnya. Sedang kewenangan pemerintah daerah di bidang pertanahan hanya dicukupkan pada aspek pelayanan masyarakat di bidang pertanahan dan pelaksanaan kebijakan nasional pertanahan dan pelaksanaan kebijakan dalam bentuk peraturan daerah atau peraturan kepala daerah.

\footnotetext{
7 Arie Sukanti Hutagalung dan Markus Gunawan, Kewenangan Pemerintah di Bidang Pertanahan, (Jakarta: Radjawali Press, 2008), hlm. 58.
} 
Kewenangan di bidang pertanahan yang dalam UUPA ditetapkan sebagai wewenang Pemerintah Pusat didasarkan pada beberapa hal, pertama, seluruh wilayah Indonesia adalah merupakan kesatuan tanah air dari seluruh rakyat Indonesia yang bersatu sebagai bangsa Indonesia. Kedua, seluruh bumi, air, dan ruang angkasa termasuk kekayaan alam yang terkandung di dalamnya adalah bumi, air, dan ruang angkasa Bangsa Indonesia dan merupakan kekayaan nasional. Ketiga, hubungan antara Bangsa Indonesia dengan bumi, air, dan ruang angkasa adalah bersifat abadi. Berdasarkan ketiga pertimbangan di atas maka tidak terlalu berlebihan jika ditetapkan dalam UUPA bahwa kewenangan untuk mengurus bidang pertanahan ada pada negara yang dalam pelaksanaannya dilakukan oleh Pemerintah Pusat.

Jadi, secara tegas UUPA yang merupakan pelaksana Pasal 33 UUD 1945 telah mengatur bahwa urusan di bidang pertanahan adalah wewenang Pemerintah Pusat. Dalam Pasal 33 UUD 1945 tidak disebutkan tentang kemungkinan penyerahan kemungkinan bumi, air, dan kekayaan alam yang terkandung di dalamnya kepada Pemerintah Daerah (i.c. Pemerintah Pusat) dan dipergunakan untuk sebesar-besarnya kemakmuran rakyat. Demikian pula, dalam penjelasan Pasal 2 UUPA telah ditegaskan bahwa berdasarkan kewenangan yang terdapat dalam hukum tanah nasional, ternyata bahwa pembentukan hukum tanah nasional maupun pelaksanaannya menurut sifat dan pada asasnya merupakan kewenangan pemerintah pusat.

Dalam rangka otonomi daerah di bidang pertanahan, pelimpahan kewenangan adalah mengenai pemerintahan, sehingga tidak berarti mencakup kewenangan di bidang hukum tanah nasional. Oleh karena itu, pertanahan sebagai salah satu bidang pemerintahan yang wajib dilaksanakan oleh pemerintah daerah, tidak harus dicerna bahwa wewenang di bidang tersebut secara utuh berada di tangan pemerintah daerah. Wewenang yang berada di tangan pemerintah daerah mengenai pertanahan harus ditafsirkan hanya sebatas yang bersifat lokalitas, tidak bersifat nasional.

Pelaksanaan yang dilimpahkan kepada pemerintah daerah dalam rangka otonomi daerah adalah pelaksanaan hukum tanah nasional. Hal ini ditegaskan dalam Pasal 2 ayat (4) UUPA bahwa hak menguasai dari negara, pelaksanaanya dapat dikuasakan kepada daerah-daerah swatantra dan masyarakat hukum adat, sekedar diperlukan dan tidak bertentangan dengan peraturan pemerintah. Dalam penjelasan Pasal 2 UUPA juga ditegaskan bahwa pelimpahan wewenang untuk melaksanakan hak penguasaan dari negara atas tanah dilakukan dalam rangka tugas pembantuan (medebewind).

Jadi, kewenangan yang pelaksanaannya dapat dilimpahkan kepada pemerintah daerah ditetapkan dalam Pasal 2 ayat (2) huruf a UUPA yang menyatakan bahwa wewenang mengatur dan menyelenggarakan peruntukan, penggunaan, persediaan tanah di daerah yang bersangkutan, sebagaimana dimaksudkan dalam Pasal 14 ayat (2) UUPA yang meliputi perencanaan 
tanah pertanian dan tanah nonpertanian sesuai dengan keadaan daerah masing-masing. Berdasarkan Pasal 14 UUPA tersebut dan dihubungkan dengan UU No. 26 Tahun 2007 tentang penataan ruang, maka Pemerintahan Daerah diberi wewenang mengatur peruntukan, penggunaan, dan persediaan serta pemeliharaan tanah. Penataan ruang meliputi suatu proses perencanaan tata ruang, pemanfaatan ruang, dan pengendalian pemanfaatan ruang.

Ketentuan Pasal 2 ayat (4) UUPA apabila dikaitkan dengan Pasal 10 ayat (5) UU No. 32 Tahun 2004, maka pelimpahan wewenang untuk melaksanakan hak menguasai Negara atas tanah dapat dilakukan melalui tugas medebewind. Segala sesuatunya akan diselenggarakan menurut keperluannya dan sudah tentu tidak boleh bertentangan dengan kepentingan nasional. Wewenang dalam bidang pertanahan dapat merupakan sumber keuangan bagi daerah. Tugas pembantuan pada dasarnya merupakan keikutsertaan daerah atau desa termasuk masyarakatnya atau penugasan atau kuasa dari pemerintah atau pemerintah daerah di atasnya untuk melaksanakan urusan pemerintah di bidang tertentu, yaitu dalam hal ini adalah bidang pertanahan. Dengan demikian maka untuk melaksanakan kewenangan di bidang pertanahan yang merupakan tugas pembantuan, pemerintah daerah dapat membentuk Dinas Pertanahan atau apabila tidak memungkinkan maka dapat melaksanakan tugas pembantuan tersebut melalui struktur pemerintahan yang ada, misalnya bagian hukum.

Menurut Budi Harsono, dalam rangka menghemat biaya dan memudahkan tersedianya pejabat pelaksana yang profesional dan berpengalaman, demikian juga dalam memelihara koordinasi dengan pelaksanaan tugas-tugas kewenangan lain di bidang pertanahan yang ada pada pemerintah, maka dalam melaksanakan urusan-urusan yang ditugaskan dalam rangka medebewind, tidak perlu pemerintah provinsi dan kabupaten/kota membentuk perangkat pelaksana sendiri. Dengan tidak mengurangi tugasnya sebagai perangkat BPN, maka cukup kantor-kantor wilayah BPN Provinsi, kantor-kantor pertanahan kabupaten/kota diperbantukan kepada pemerintah provinsi atau kabupaten/kota yang bersangkutan dengan tetap berstatus perangkat pemerintah pusat, demikian juga para pejabat dan pegawainya. ${ }^{8}$

\section{b. Kewenangan Pemerintah Pusat dan Daerah dalam Mengurus Bidang Pertanahan Menurut Undang-Undang No. 32 Tahun 2004}

Urusan di bidang pertanahan merupakan salah satu urusan yang wajib dilaksanakan oleh pemerintah daerah, baik pemerintah provinsi maupun

\footnotetext{
${ }^{8}$ Budi Harsono, 46 Tahun UUPA, Usaha Penyempurnaan yang Belum Selesai, Makalah pada Pertemuan Tahunan Memperingati Hari Ulang Tahun UUPA, Jakarata, 14 September 2006, hlm. 12. Lihat juga Arie Sukanti Hutagalung, 2008, Op Cit, hlm. 119.
} 
pemerintah kabupaten/kota sesuai masing-masing daerah. Hal ini berbeda dengan Undang-Undang No. 22 Tahun 1999 yang hanya memberikan pelimpahan urusan di bidang pertanahan kepada pemerintah kabupaten/kota selaku daerah otonom, sedangkan pemerintah provinsi tidak diberi pelimpahan wewenang untuk mengurusi bidang pertanahan. Dalam UndangUndang No. 32 Tahun 2004 kewenangan mengurus bidang pertanahan diberikan secara lebih luas kepada pemerintah provinsi, yakni termasuk mengurus bidang pelayanan pertanahan lintas kabupaten/kota. Dalam Pasal 13 ayat (1) Undang-Undang No. 32 Tahun 2004 disebutkan bahwa urusan wajib yang menjadi kewenangan pemerintahan daerah provinsi merupakan urusan dalam skala provinsi meliputi:

1) perencanaan dan pengendalian pembangunan;

2) perencanaan, pemanfaatan, dan pengawasan tata ruang;

3) penyelenggaraan ketertiban umum dan keteraturan masyarakat;

4) penyediaan sarana dan prasana umum;

5) penanganan bidang kesehatan;

6) penyelenggaraan pendidikan dan alokasi sumber daya manusia potensial;

7) penanggulangan masalah sosial lintas kabupaten/kota;

8) pelayanan bidang ketenagakerjaan lintas kabupaten/kota;

9) fasilitas pengembangan koperasi, usaha kecil, dan menengah termasuk lintas kabupaten/kota;

10) pengendalian lingkungan hidup;

11) pelayanan pertanahan termasuk lintas kabupaten/kota;

12) pelayanan pendudukan dan catatan sipil;

13) pelayanan administrasi umum pemerintahan;

14) pelayanan administrasi penanaman modal termasuk lintas kabupaten/kota;

15) penyelenggaraan pelayanan dasar lainnya yang belum dapat dilaksanakan oleh kabupaten/kota; dan

16) urusan wajib lainnya yang diamanatkan oleh peraturan perundangundangan.

Dari ketentuan dalam Pasal 13 ayat (1) huruf k Undang-Undang No. 32 Tahun 2004 terlihat bahwa urusan pelayanan pertanahan menjadi salah satu urusan wajib yang harus dilaksanakan oleh Pemerintah Provinsi. Selanjutnya mengenai urusan wajib yang harus dilaksanakan oleh pemerintah kabupaten/kota disebutkan dalam Pasal 14 ayat (1) UndangUndang No. 32 Tahun 2004 meliputi:

1) perencanaan dan pengendalian pembangunan;

2) perencanaan, pemanfaatan, dan pengawasan tata ruang;

3) penyelenggaraan ketertiban umum dan keteraturan masyarakat;

4) penyediaan sarana dan prasarana umum; 
5) penanganan bidang kesehatan;

6) penyelenggaraan pendidikan dan alokasi sumber daya manusia potensial;

7) penanggulangan masalah sosial lintas kabupaten/kota;

8) pelayanan bidang ketenagakerjaan lintas kabupaten/kota;

9) fasilitas pengembangan koperasi, usaha kecil, dan menengah termasuk lintas kabupaten/kota;

10) pengendalian lingkungan hidup;

11) pelayanan pertanahan termasuk lintas kabupaten/kota;

12) pelayanan pendudukan dan catatan sipil;

13) pelayanan administrasi umum pemerintahan;

14) pelayanan administrasi penanaman modal termasuk lintas kabupaten/kota;

15) penyelenggaraan pelayanan dasar lainnya yang belum dapat dilaksanakan oleh kabupaten/kota; dan

16) urusan wajib lainnya yang diamanatkan oleh peraturan perundangundangan.

Berdasarkan dalam Pasal 13 ayat (1.k) dan Pasal 14 ayat (1.k) Undang-Undang No. 32 Tahun 2004 maka urusan pelayanan pertanahan menjadi kewenangan pemerintah provinsi dan pemerintah kabupaten/kota untuk diselenggarakan dalam kaitannya dengan otonomi daerah. Atau dengan kata lain "pelayanan pertanahan" menjadi urusan pemerintahan yang wajib dilaksanakan oleh pemerintah provinsi dan pemerintah kabupaten/kota. Semestinya pemerintah pusat terutama instansi yang mengurusi pertanahan secara bertahap menyelaraskan urusan pelayanan bidang pertanahan kepada pemerintah daerah (provinsi dan kabupaten).

\section{c. Kewenangan Pemerintah Pusat dan Daerah dalam Mengurus Bidang Pertanahan menurut Peraturan Pemerintah No. 38 Tahun 2007}

Untuk menjabarkan pelaksanaan otonomi daerah sebagaimana diamanatkan UU No. 32 Tahun 2004 kemudian diterbitkan PP No. 38 Tahun 2007 tentang Pembagian Urusan Pemerintahan antara Pemerintah, Pemerintah Daerah Provinsi, dan Pemerintah Daerah Kabupaten/ Kota. Dalam PP No. 38 Tahun 2007 disebutkan bahwa urusan pemerintahan terdiri atas urusan pemerintahan yang sepenuhnya menjadi kewenangan pemerintah pusat, dan urusan pemerintahan yang dibagi bersama antar tingkatan dan/ atau susunan pemerintahan. Urusan pemerintahan yang sepenuhnya menjadi urusan pemerintah pusat meliputi politik luar negeri, pertahanan, keamanan, yustisi, moneter, dan fiskal nasional, serta agama. Sedang urusan pemerintahan yang dibagi bersama antar tingkatan dan/atau susunan 
pemerintahan adalah semua urusan pemerintahan di luar enam urusan tersebut. ${ }^{9}$

Dalam Pasal 2 ayat (4) PP No. 38 Tahun 2007 disebutkan bahwa urusan pemerintahan yang dibagi bersama antar tingkatan dan/atau susunan pemerintahan (provinsi dan kabupaten/kota) terdiri atas 31 bidang urusan pemerintahan yang meliputi:

1) pendidikan;

2) kesehatan;

3) pekerjaan umum;

4) perumahan;

5) penataan ruang;

6) perecanaan pembangunan;

7) perhubungan;

8) lingkungan hidup;

9) pertanahan;

10) kependudukan dan catatan sipil;

11) pemberdayaan perempuan dan perlindungan anak;

12) keluarga berencana dan keluarga sejahtera;

13) sosial;

14) ketenagakerjaan dan ketransmigrasian;

15) koperasi dan usaha kecil dan menengah;

16) penanaman modal;

17) kebudayaan dan pariwisata;

18) kepemudaan dan olahraga;

19) kesatuan bangsa dan politik dalam negeri;

20) otonomi daerah, pemerintahan umum, administrasi keuangan daerah, perangkat daerah, kepegawaian, dan persandian;

21) pemberdayaan masyarakat dan desa;

22) statistik;

23) kearsipan;

24) perpustakaan;

25) komunikasi dan informatika;

26) pertanian dan ketahanan pangan;

27) kehutanan;

28) energi dan sumber daya mineral;

29) kelautan dan perikanan;

30) perdagangan; dan

31) perindustrian.

Dari ke-31 urusan pemerintahan yang oleh pemerintah dilimpahkan kepada pemerintah daerah (provinsi dan kabupaten/kota) menurut PP No. 38

\footnotetext{
${ }^{9}$ Suriansyah Murhaini, Op Cit, hlm. 77.
} 
Tahun 2007 tersebut termasuk didalamnya adalah urusan di bidang "pertanahan" bulan "pelayanan pertanahan" sebagaimana disebut dalam UU No. 32 Tahun 2004. Mestinya dalam PP No. 38 Tahun 2007 disebutkan sebagai urusan di bidang "pelayanan pertanahan" bukan "pertanahan". Urusan bidang pertanahan hanya menjadi kewenangan Pemerintah Pusat, sedang yang dilimpahkan kepada pemerintah daerah adalah "pelayanan pertanahan". Hal itu berarti terjadi kontradiksi antara ketentuan dalam UU No. 32 Tahun 2004 dengan PP No. 38 Tahun 2007. Dengan mengacu pada teori hierarki hukum dan asas lex superiori derogate legi inferiori, maka ketentuan yang seharusnya diberlakukan adalah sebagaimana yang tercantum dalam UU No. 32 Tahun 2004, khususnya Pasal 13 dan Pasal 14.

Adapun perincian kewenangan di bidang pertanahan yang masih diurusi oleh Pemerintah Pusat termuat dalam lampiran PP No. 38 Tahun 2007 huruf I, yaitu sebagai berikut:

1) subbidang: izin lokasi, kewenangan pemerintah meliputi:

a) penetapan kebijakan nasional mengenai norma, standar, prosedur, dan kriteria izin lokasi;

b) pemberian izin lokasi lintas provinsi;

c) pembatalan izin lolaksi atas usulan pemerintah provinsi dengan pertimbangan kepala kantor wilayah BPN provinsi; dan

d) pembinaan, pengendalian, dan monitoring terhadap pelaksanaan izin lokasi.

2) subbidang: pengadaan tanah untuk kepentingan umum, meliputi:

a) penetapan kebijakan nasional mengenai norma, standar, prosedur, dan kriteria pengadaan tanah untuk kepentingan umum;

b) pengadaan tanah untuk pembangunan lintas provinsi; dan

c) pembinaan, pengendalian, dan monitoring terhadap pelaksanaan pengadaan tanah untuk kepentingan umum.

3) subbidang: penyelesaian sengketa tanah garapan, meliputi:

a) penetapan kebijakan nasional mengenai norma, standar, prosedur, dan kriteria penyelesaian sengketa tanah garapan; dan

b) pembinaan, pengendalian, dan monitoring terhadap pelaksanaan penanganan sengketa tanah garapan.

4) Subbidang: penyelesaian masalah ganti kerugian dan santunan tanah untuk pembangunan, yang meliputi:

a) penetapan kebijakan nasional mengenai norma, standar, prosedur, dan kriteria penyelesaian masalah ganti kerugian dan santunan tanah untuk pembangunan; dan

b) pembinaan, pengendalian, dan monitoring terhadap pelaksanaan pemberian ganti kerugian dan santunan tanah untuk pembangunan.

5) subbidang: penetapan subjek dan objek redistribusi tanah, serta ganti kerugian tanah kelebihan maksimum dan tanah absentee, yang meliputi: 
a) penetapan kebijakan nasional mengenai norma, standar, prosedur, dan kriteria penetapan subjek dan objek redistribusi tanah, serta ganti kerugian tanah kelebihan maksimum dan tanah absentee;

b) pembentukan panitia pertimbangan landreform nasional; dan

c) pembinaan, pengendalian, dan monitoring terhadap pelaksanaan penetapan subjek dan objek redistribusi tanah, serta ganti kerugian tanah kelebihan maksimum dan tanah absentee.

6) subbidang: penetapan tanah ulayat, yang meliputi:

a) penetapan kebijakan nasional mengenai norma, standar, prosedur, dan kriteria penetapan dan penyelesaian masalah penetapan tanah ulayat dan;

b) pembinaan, pengendalian, dan monitoring terhadap pelaksanaan penetapan dan penyelesaian masalah penetapan tanah ulayat.

7) subbidang: pemanfaatan dan penyelesaian masalah tanah kosong, yang meliputi:

a) penetapan kebijakan nasional mengenai norma, standar, prosedur, dan kriteria serta pelaksanaan pembinaan dan pengendalian pemanfaatan dan penyelesaian masalah tanah kosong; dan

b) pembinaan, pengendalian, dan monitoring terhadap pelaksanaan pemanfaatan dan penyelesaian masalah tanah kosong.

8) subbidang: izin membuka tanah, yang meliputi:

a) penetapan kebijakan nasional mengenai norma, standar, prosedur, dan kriteria serta pelaksanaan pembinaan dan pengendalian pemberian izin membuka tanah dan;

b) pembinaan, pengendalian, dan monitoring terhadap pelaksanaan izin membuka tanah.

9) subbidang: perencanaan penggunaan tanah wilayah kabupaten/kota, kewenangan pemerintah meliputi:

a) penetapan kebijakan nasional mengenai norma, standar, prosedur, dan kriteria perencanaan penggunaan tanah wilayah kabupaten/kota; dan

b) pembinaan, pengendalian, dan monitoring terhadap pelaksanaan perencanaan penggunaan tanah wilayah kabupaten/kota.

Dari perincian kewenangan yang dimiliki oleh pemerintah pusat di bidang pertanahan sebagaimana tersebut di atas terlihat bahwa isi kewenangan pemerintah pusat adalah pada tataran pembuatan kebijakan dan pengaturan/regulasi yang meliputi sembilan subbidang. Kewenangan pemerintah pusat adalah penetapan kebijakan dan pembuatan produk hukum tanah serta melakukan pembinaan, pengendalian, dan pengawasan terhadap pelaksanaan kebijakan yang telah diterbitkan. Jadi, pemerintah bertindak selaku pengambil keputusan dan pembuat kebijakan di bidang pertanahan, sedang pada tataran pelaksanaanya dilimpahkan kepada pemerintah daerah (pemerintah provinsi dan kabupaten/kota). Dengan demikian kendali 
pengambil kebijakan di bidang pertanahan secara nasional tetap berada di tangan pemerintah pusat, sementara pemerintah daerah hanya melaksanakan saja semua kebijakan yang telah diambil oleh pemerintah pusat di bidang pertanahan tersebut. Hal ini menunjukan bahwa otonomi daerah di bidang pertanahan tidak sepenuhnya diserahkan kepada daerah, dalam arti pemerintah daerah menerbitkan aturan, tetapi hanya pada tahap pelaksanaan saja, atau lebih pada tataran teknis administrasi di lapangan.

\section{Analisis Hubungan Kewenangan Pemerintah Pusat dan Daerah dalam Mengurus Bidang Pertanahan}

Dari uraian pembahasan pertama dapat penulis analisis hubungan kewenangan pemerintah pusat dan daerah dalam mengurus bidang pertanahan sebagai berikut, yaitu:

Pertama,menurut Undang-Undang Pokok Agraria (UU No. 5 Tahun 1960) pengurusan di bidang pertanahan merupakan wewenang pemerintah pusat. Pemerintah memandang urusan pertanahan merupakan masalah hukum nasional sehingga tidak dapat ditimpahkan kepada pemerintah daerah (provinsi dan kabupaten/kota). Kendati telah diserahkan kepada daerah otonom berdasarkan Pasal 11 ayat (2) Undang-Undang No. 22 Tahun 1999 yang kemudian diganti dengan Pasal 13 dan 14 Undang-Undang No. 32 tahun 2004, namun karena menyangkut bidang hukum tanah dan kebijakan di bidang pertanahan bersifat nasional maka masih tetap diurus oleh pemerintah, tidak dilimpahkan kepada daerah otonom. Perintah hingga saat ini belum menghendaki bidang pertanahan diurusi oleh pemerintah daerah (provinsi dan kabupaten/kota). Hal itu terbukti dari adanya peraturan perundang-undangan yang menganulir bidang pertanahan dan adanya kebijakan pemerintah untuk tetap mempertahankan eksistensi badan pertanahan nasional dan instansi vertikal di daerah, yaitu kantor wilayah bpn provinsi dan kantor pertanahan kabupaten/kota sebagaimana diatur dalam peraturan presiden No. 10 Tahun 2006.

Dalam rangka pelaksanaan otonomi daerah di bidang pertanahan di beberapa pemerintah daerah sempat di bentuk dinas pertanahan. Namun, pembentukan dinas pertanahan di beberapa daerah tersebut pada kenyataannya tidak operasional karena pemerintah tetap mempertahankan keberadaan Kantor Wilayah BPN Provinsi dan kantor Pertanahan Kabupaten/Kota sebagai instansi vertikal pusat di daerah yang mengurusi masalah pertanahan. Tidak direalisasikannya pembentukan dinas pertanahan oleh pemerintah daerah dimaksudkan untuk menghindari terjadinya konflik atau benturan kepentingan antara Badan Pertanahan Nasional dan Dinas Pertanahan Daerah. Disamping itu juga kebingungan dalam meminta layanan di bidang pertanahan. 
Kedua, dalam Undang-Undang No. 32 Tahun 2004 ditentukan bahwa urusan pemerintah di bidang pelayanan pertanahan diserahkan kepada pemerintah daerah sebagai urusan yang wajib dilaksanakan. Hanya saja proses penyerahan wewenang tersebut tidak dapat berjalan karena peraturan pelaksana yang diterbitkan Pemerintah menganulir kewenangan pemerintah daerah dalam mengurusi bidang pertanahan. Bidang pertanahan yang dapat diurusi oleh pemerintah daerah hanya menyangkut kebijakan, sementara mengenai perbuatan kebijakan hukum di bidang pertanahan secara nasional tetap menjadi wewenang pemerintah. Bidang pertanahan yang selama ini ditangani pemerintah daerah hanya menyangkut pengaturan dan pengurusan tanah-tanah (aset) yang dimiliki atau dikuasai pemerintah daerah.

Dalam PP No. 38 Tahun 2007 yang mengatur pembagian wewenang pemerintahan antara pemerintah, pemerintah provinsi, dan pemerintah kabupaten/kota, juga ditentukan bahwa urusan bidang pertanahan secara nasional masih tetap menjadi kewenangan pemerintah. Namun urusan bidang pertanahan dapat dilimpahkan (diserahkan) kepada pemerintah daerah, tetapi hanya sebatas pada pelayanan pertanahan, yakni pertanahan secara nasional tetap diputuskan pemerintah. Dalam PP No. 41 Tahun 2007 yang mengatur urusan bidang pelayanan pertanahan dapat ditangani oleh lembaga setingkat dinas, namun dalam praktek saat ini belum ada pemerintah daerah yang membentuk dinas pertanahan daerah, karena dikhawatirkan tidak efektif dan tidak operasional seperti yang pernah terjadi pada era sebelum Undang-Undang No. 32 Tahun 2004.

Ketiga untuk menganulir kontradiksi terkait penyerahan kewenangan untuk urusan bidang pertanahan kepada pemerintah daerah, maka seharusnya pemerintah mengkaji ulang perihal kewenangan urusan pemerintahan dibidang pertanahan, apakah memang tetap ditentukan sebagai kewenangan pemerintah atau dilimpahkan kepada pemerintah daerah. Apabila mengacu kepada pasal 33 Undang-Undang Dasar 1945 dan Undang-Undang No. 5 Tahun 1960, maka urusan di bidang pertanahan menjadi kewenangan Pemerintah. Tetapi tentu saja hal ini bertentangan dengan Undang-Undang No. 32 Tahun 2004 yang saat ini masih berlaku yang menyatakan bahwa urusan bidang pelayanan pertanahan diserahkan kepada pemerintah daerah sebagai urusan wajib. Seyogyanya kalau kita mengacu kepada UUD 1945 dan UUPA urusan pertanahan yang menyangkut hukum tanah nasional tetap menjadi kewenangan pemerintah, sedangkan untuk pelimpahan wewenang kepada pemerintah daerah dapat dilakukan tetapi hanya berdasarkan prinsip tugas pembantuan (medebewid), bukan melalui desentralisasi seperti yang selama ini ditentukan dalam Undang-Undang No. 32 Tahun 2004. Oleh karena itu, perlu dilakukan sinkronisasi antara UUPA dengan UndangUndang Pemerintahan Daerah, khususnya menyangkut kewenangan dalam mengurus bidang pertanahan. 


\section{Penutup}

\section{Kesimpulan}

a. menurut Undang-Undang Pokok Agraria (UU No. 5 Tahun 1960) pengurusan di bidang pertanahan merupakan wewenang Pemerintah pusat. Pemerintah memandang urusan pertanahan merupakan masalah hukum nasioanal sehingga tidak dapat ditimpahkan kepada pemerintah daerah (provinsi dan kabupaten/kota). Kendati telah diserahkan kepada daerah otonom berdasarkan Pasal 11 ayat (2) Undang-Undang No. 22 Tahun 1999 yang kemudian diganti dengan Pasal 13 dan 14 UndangUndang No. 32 Tahun 2004, namun karena menyangkut bidang hukum tanah dan kebijakan di bidang pertanahan bersifat nasional maka masih tetap diurus oleh pemerintah, tidak dilimpahkan kepada daerah otonom.

b. Pemerintah mengkaji ulang perihal kewenangan urusan pemerintahan dibidang pertanahan, apakah memang tetap ditentukan sebagai kewenangan pemerintah atau dilimpahkan kepada pemerintah daerah. Apabila mengacu kepada pasal 33 Undang-Undang Dasar 1945 dan Undang-Undang No. 5 Tahun 1960, maka urusan di bidang pertanahan menjadi kewenangan pemerintah. Tetapi tentu saja hal ini bertentangan dengan Undang-Undang No. 32 Tahun 2004 yang saat ini masih berlaku yang menyatakan bahwa urusan bidang pelayanan pertanahan diserahkan kepada pemerintah daerah sebagai urusan wajib.

\section{Saran}

a. Pembaharuan kebijakan di bidang pertanahan harus memperhatikan penyebaran pengurusan tanah secara adil bagi rakyat sesuai kebutuhan dan kemampuannya. Untuk itu perlu penataan kembali sistem pengurusan tanah, baik menyangkut pembaharuan hak atas tanah maupun sistem tata guna tanah.

b. Dihilangkan dualisme sistem pertanahan yang tidak adil dan merugikan rakyat. Sistem baru di bidang pertanahan harus mencangkup sistem penguasaan tanah, sistem administrasi pertanahan, dan kepastian hukum, baik dalam proses maupun dalam berbagai hak penguasaan atas tanah.

\section{Daftar Pustaka}

\section{A. Buku}

Hadjon, Philipus M., 1994. Fungsi Normatif Hukum Administrasi dalam Mewujudkan Pemerintah yang Bersih, Pidato Pengukuhan Guru Besar UNAIR, Surabaya. 
Harsono, 46 Tahun UUPA, Usaha Penyempurnaan yang Belum Selesai, Makalah pada Pertemuan Tahunan Memperingati Hari Ulang Tahun UUPA, Jakarata.

Hutagalung, Arie Sukanti, dan Markus Gunawan, Kewenangan Pemerintah di Bidang Pertanahan, Radjawali Press, Jakarta.

Marbun S.F., 1997. Peradilan Administrasi Negara dan Upaya Administratif di Indonesia, Yogyakarta: Liberty.

Murhaini, Suriansyah, Kewenangan Pemrintah Daerah Mengurus Bidang Pertanahan, LaksBang Justitia, Surabaya.

Stroink, F.A.M., dalam Philips M. Hadjon, sebagaimana dikutip Sadjijno, 2008. Memahami Beberapa Bab Hukum Administrasi, Yogyakarta: LaksBang PRESindo.

\section{B. Peraturan Perundang Undangan}

Undang-Undang Nomor 5 Tahun 1960 tentang Pokok Agraria.

Undang-Undang Nomor 32 Tahun 2004 tentang Pemerintahan Daerah.

Peraturan Pemerintah No. 38 Tahun 2007 tentang Pembagian Urusan Pemerintahan antara Pemerintah, Pemerintah Daerah Provinsi dan Pemerintah Daerah Kabupaten/Kota. 